\title{
Correlation between Body Mass Index and Serum Leptin Level in Patients with Polycystic Ovary Syndrome
}

\author{
Erna Jupri, ${ }^{1,2}$ Anna Tjandrawati, ${ }^{2}$ Hartanto Bayuaji, ${ }^{3}$, Sylvia Rachmayati, ${ }^{2}$ Ida Parwati ${ }^{2}$ \\ ${ }^{1}$ Boven Digoel District Health Office, Papua, Indonesia, ${ }^{2}$ Department of Clinical Pathology Faculty of Medicine \\ Universitas Padjadjaran/Dr. Hasan Sadikin General Hospital Bandung, Indonesia, ${ }^{3}$ Department of Obstetrics and \\ Gynecology Faculty of Medicine Universitas Padjadjaran/Dr. Hasan Sadikin General Hospital Bandung, Indonesia
}

\begin{abstract}
Polycystic ovary syndrome (PCOS) is the most common endocrine abnormality in reproductive-age women, which is characterized by hyperandrogenism, anovulation, and polycystic ovaries. Some evidence suggested that leptin also causes PCOS due to its role in female reproductive system. The physiological function of leptin controls the balance of energy and suppresses the center of appetite. Patients with PCOS maybe underweight, normoweight, overweight, and obese, based on their body mass index (BMI), but obesity is a common clinical situation in PCOS. Obesity occurs when the level of leptin increases but cannot decrease appetite, resulting in leptin resistance. This study aimed to discover the connection between BMI and the level of leptin in patients with PCOS. This was a cross-sectional observational analytic performed in Dr. Hasan Sadikin General Hospital Bandung between April 25 and July 10, 2018. Subjects included 46 PCOS patients who were diagnosed based on Rotterdam criteria by gynecology obstetricians in the hospital. Enzyme-linked immunosorbent assay (ELISA) was used to examine the leptin serum levels. Leptin level increased 74\%, mostly in obese patients that comprised $41 \%$ of these subjects. Normal leptin levels was seen in $26 \%$ of patients, none of them was obese. The Spearman Rank correlation test showed a significant positive correlation between BMI and leptin levels ( $r=0.644, p=0.000)$. Hence, a high body mass index in people with PCOS positively correlates with increased leptin level.
\end{abstract}

Key words: Body mass index, leptin hormone, polycystic ovary syndrome

\section{Korelasi antara Indeks Massa Tubuh dan Kadar Leptin Serum pada Penderita Sindrom Ovarium Polikistik}

\begin{abstract}
Abstrak
Sindrom Ovarium Polikistik (SOPK) merupakan kelainan endokrin pada wanita reproduktif yang ditandai oleh hiperandrogenisme, anovulasi, dan ovarium polikistik. Terdapat beberapa bukti bahwa leptin turut menyebabkan SOPK karena leptin berperan dalam sistem reproduksi wanita. Fungsi fisiologis leptin mengendalikan keseimbangan energi dan menekan pusat nafsu makan. Penderita SOPK dapat memiliki indeks massa tubuh (IMT) underweight, normoweight, overweight dan obese, namun obesitas merupakan gambaran klinis yang umum terjadi pada SOPK. Obesitas terjadi bila peningkatan kadar leptin, namun leptin tidak mampu bekerja menurunkan nafsu makan sehingga terjadi resistensi leptin. Penelitian ini bertujuan mengetahui hubungan IMT dengan kadar leptin pada penderita SOPK. Penelitian ini berbentuk analitik observasional dengan rancangan potong lintang dan dilakukan di Rumah Sakit Umum Pusat Dr. Hasan Sadikin (RSHS) Bandung pada tanggal 25 April-10 Juli 2018. Subjek penelitian sebanyak 46 penderita SOPK yang didiagnosis berdasar atas kriteria Rotterdam oleh klinisi obstetri ginekologi RSHS. Pemeriksaan kadar leptin serum mengunakan metode Enzyme-linked immunosorbent assay (ELISA). Kadar leptin yang meningkat 74\% terbanyak pada IMT obese $41 \%$ subjek, dan kadar leptin normal 26\% tidak ditemukan pada subjek yang IMT obese. Uji korelasi Rank Spearman menunjukkan korelasi positif kuat yang bermakna antara IMT dan kadar leptin $(\mathrm{r}=0,644 ; \mathrm{p}=0,000)$. Indeks massa tubuh yang tinggi pada penderita SOPK berkorelasi positif dengan peningkatan kadar leptin.
\end{abstract}

Kata kunci: Hormon leptin, indeks massa tubuh, sindrom ovarium polikistik

Corresponding Author: Erna Jupri, Boven Digoel District Health Office, Papua, Jalan Trans Papua No. Km. 05, Persatuan, Kec. Mandobo, Kabupaten Boven Digoel, Papua 99663, Indonesia, Email: erna.jupri35@gmail.com 


\section{Introduction}

Polycystic ovary syndrome (PCOS) is an endocrine disorder characterized by ovarian dysfunction (anovulation or oligo-ovulation), hyperandrogenism, and multiple ovarian follicles. The multiple ovarian follicles occur if ovarian has follicles less than $10 \mathrm{~mm}$ in diameter with 12 or more surrounding the ovarian stroma. The PCOS has multifactorial causes including, among others, lifestyle, such as uncontrolled eating patterns and lack of physical activity; the presence of genetic predisposition (hereditary); and hormonal factors imbalance. ${ }^{1,2}$ Azziz et al. ${ }^{3}$ has found that the global prevalence of PCOS is $5-20 \%$. This prevalence depends on the criteria used to diagnose PCOS. ${ }^{4}$ Santoso et al. $^{5}$ in Surabaya found a PCOS prevalence of $4.5 \%$, giving an overview of POCS prevalence data in Indonesia. In the long term, a PCOS patient, who is not treated and does not change lifestyle, can experience various complications such as infertility, type 2 diabetes mellitus (DMT 2), cardiovascular diseases, and metabolic syndrome. Good management and lifestyle modification play an important role to reduce the risks of long-term complications of PCOS. ${ }^{1}$

There are three criteria to diagnose PCOS: (1) the 1992 criteria of the National Institutes of Health (NIH) 1992, (2) the 2004 consensus of the European Society of Human Reproduction and Embryology (ESHRE) and the American Society for Reproductive Medicine (ASRM), and (3) the 2006 criteria of the Androgen Excess Society. ${ }^{4}$ The 2004 consensus of the European Society of Human Reproduction and Embryology (ESHRE) and the American Society for Reproductive Medicine (ASRM) produces a diagnosis criteria for polycystic syndrome ovaries, known as the Rotterdam criteria. Based on the Rotterdam criteria, PCOS diagnosis is established when two of the three criteria are met. For instance, the diagnosis procedure finds clinical and biochemical hyperandrogenism; oligo-ovulation or anovulation; and polycystic ovaries. ${ }^{4}$

Polycystic ovary syndrome can be found in women of reproductive age with various types of weights based on BMI. These include women who are underweight, normoweight, overweight, and obese. Yet, about $50-60 \%$ of PCOS sufferers are obese. Obesity, in addition to an increase of ob gene expression in the subcutaneous fat tissue, can also cause a disruption of leptin transport through the hypothalamus which, causing leptin resistance and hyperleptinemia. 6,7

The leptin hormone is a polypeptide hormone produced and secreted by white adipose tissue that functions to transmit metabolic signals to the brain nerve tissue to modulate the hypothalamus-pituitary-ovary. Leptin resistance is associated with obesity and persistent hyperphagia, resulting in hyperinsulinemia that will then lead to insulin resistance. ${ }^{8,9}$ Hyperinsulinemia decreases the level of sex hormone binding globulin (SHBG) in the liver, leading to an increased androgen level in the ovary. Hyperinsulinemia, together with an increase of luteinizing hormone (LH), can increase the androgen level in ovary that will trigger hyperandrogenemia as a symptom of PCOS.

Hyperleptinemia will affect the receptors in hypothalamus, causing changes in gonadotropine releasing hormone (GnRH) secretion. An increase in GnRH level may cause disruption of LH secretion which then causes an increase in ovarian androgen level. ${ }^{6,7}$ Increased androgens may cause hyperandrogenemia that inhibits follicular development and causes anovulation, infertility, and polycystic ovaries, which comprise the symptoms of PCOS. ${ }^{7,10}$ This study aimed to measure the correlation of serum leptin hormone level and body mass index (BMI) in patients with PCOS.

\section{Methods}

This was a cross-sectional observational analytic study on infertile women aged 20-39 years who had been diagnosed carrying PCOS based on the 2004 Rotterdam criteria by a specialist at the obstetrics and gynecology department of Dr. Hasan Sadikin General Hospital Bandung, Indonesia, during the period of April 25-July 10, 2018. The exclusion criteria in this study were underlying diseases such as diabetes mellitus, hypertension, heart disorder, tuberculosis, thyroid, rheumatoid arthritis, examined by hemolysis serum, icteric, and lipemic. Data collected were subsequently analyzed using the Statistical Package for the Social Sciences (SPSS) for Windows version 24.0.

Based on the International Diabetes Federation, the normal serum leptin level is between $4.1-11.0 \mathrm{ng} / \mathrm{mL}$. with a serum leptin level of $<4.1 \mathrm{ng} / \mathrm{mL}$ is considered low and a serum leptin level of $>11.0 \mathrm{ng} / \mathrm{mL}$ is considered high. ${ }^{11}$ The body mass index (BMI) data was categorized based on Asia Pacific criteria: underweight when the BMI is $<18.5 \mathrm{~kg} / \mathrm{m}^{2}$, normoweight when the BMI is $18.5-22.9 \mathrm{~kg} / \mathrm{m}^{2}$, 
overweight when the BMI is $23.0-24.9 \mathrm{~kg} / \mathrm{m}^{2}$, and obese when the BMI is $\geq 25 \mathrm{~kg} / \mathrm{m}^{2} .^{12}$

The examination materials of the study consisted of serum derived from the venous blood of the study subjects. Sampling was performed using the phlebotomy procedure for examination of leptin level. Sample was then centrifuged at a speed of $1.000 \mathrm{~g}$ for 15 minutes until the serum was formed. The serum was subsequently put into a 200 micron plasticmicrotube and then stored at $-80^{\circ} \mathrm{C}$. Examination of leptin hormone level was carried out in July 2018 at the Clinical Pathology Laboratory of the hospital using sandwich micro Enzyme-linked immunosorbent assay (ELISA) assay. The required number of samples for this study was determined using the sample size formula of the Spearman Rank correlation analysis with a degree of confidence of $95 \%$, requiring samples from 46 subjects. Ethical clearance for this study was obtained from the Health Research Ethics Committee of the Faculty of Medicine, Universitas Padjadjaran with the issuance of the ethical clearance number LB.04.01/A05/EC/125/IV/2018.

\section{Results}

The BMI classification applied in this study was the Asia-Pacific criteria with $\mathrm{BMI}<18.5 \mathrm{~kg} / \mathrm{m}^{2}$ as underweight, $18.5-22.9 \mathrm{~kg} / \mathrm{m}^{2}$ as normoweight, $23.0-24.9 \mathrm{~kg} / \mathrm{m}^{2}$ as overweight, and $\geq 25 \mathrm{~kg} / \mathrm{m}^{2}$ as obese.

Normal leptin level in blood, according to the International Diabetes Federation (IDF), ranges between $4.1-11.0 \mathrm{ng} / \mathrm{mL}^{11}$

Results of the Rank Spearman correlation test on the correlation between leptin level and body mass index resulted in a strong positive correlation ( $\mathrm{r}=0.644, \mathrm{p}=0.000)$, which was statistically significant. A positive correlation
Table 1 Subject Characteristics

\begin{tabular}{lcc}
\hline \multicolumn{1}{c}{ Variable } & $\begin{array}{c}\text { Number } \mathbf{n} \\
\text { (\%) }\end{array}$ & $\begin{array}{c}\text { Median } \\
\text { (Range) }\end{array}$ \\
\hline Age (year) & & $\begin{array}{c}20-39 \\
23.0 \\
(16.9-37.1)\end{array}$ \\
BMI $\left(\mathrm{kg} / \mathrm{m}^{2}\right)$ & & \\
Underweight & 10 & \\
$<18.5$ & & \\
Normoweight & $22(48)$ & \\
18.5-22.9 & & \\
Overweight & $9(20)$ & \\
23-24.9 & $14(30)$ & \\
Obese $\geq 25$ & & \\
Leptin (ng/mL) & & \\
Increase & $34(74)$ & \\
$>11.0$ ng/mL & & \\
Normal & $12(26)$ & \\
4.1-11.0 ng/mL & \\
Change of Lifestyle & \\
Exercise & $5(54)$ \\
$\geq 3 x /$ week & $14(30)$ \\
Aerobic & $9(20)$ \\
Jogging & $2(4)$ \\
Swimming & $7(15)$ & \\
Exercise $<3 x /$ week & & \\
No exercise & & \\
\hline
\end{tabular}

means that the higher the body mass index is, the higher the level of leptin in PCOS subjects.

Differences of body mass index classification (underweight, normoweight, overweight, and obese) and serum leptin level in PCOS patients were then tested using chi square. (Table 2).

Women with obese PCOS have a higher level of leptin (Table 2). The state of obesity is

\section{Table 2 Proportion of Classification of Body Mass Index and Serum Leptin Hormone Levels in} Women with PCOS

\begin{tabular}{|c|c|c|c|}
\hline \multirow{2}{*}{$\begin{array}{c}\text { Classification of BMI } \\
\left(\mathrm{kg} / \mathrm{m}^{2}\right)\end{array}$} & \multicolumn{2}{|c|}{ Leptin (ng/mL) } & \multirow[b]{2}{*}{$\mathbf{p}$} \\
\hline & $\begin{array}{c}\text { Increase n (34) } \\
\text { n (\%) } \\
\text { Leptin >11ng/mL }\end{array}$ & $\begin{array}{c}\text { Normal n(12) } \\
n(\%) \\
\text { Leptin } \leq 11 \mathrm{ng} / \mathrm{mL}\end{array}$ & \\
\hline Underweight & $0(0.0)$ & $1(8)$ & \multirow{4}{*}{$0.01^{*}$} \\
\hline Normoweight & $13(38)$ & $9(75)$ & \\
\hline Overweight & $7(21)$ & $2(17)$ & \\
\hline Obese & $14(41)$ & $0(0.0)$ & \\
\hline
\end{tabular}

\footnotetext{
${ }^{*} \mathrm{p}<0.05=$ Significant
} 
Jupri, et al: Correlation between Body Mass Index and Serum Leptin Level in Patients with Polycystic Ovary Syndrome

Table 3 Exercise, BMI, and Leptin Level

\begin{tabular}{|c|c|c|c|c|c|c|}
\hline \multirow{2}{*}{ Variable } & \multicolumn{4}{|c|}{ Body Mass Index } & \multicolumn{2}{|c|}{ Leptin Level } \\
\hline & Underweight & Normoweight & Overweight & Obese & Increase & Normal \\
\hline \multicolumn{7}{|c|}{ Exercise $\geq 3 x /$ week } \\
\hline Aerobic & & 12 & 2 & 1 & 7 & 7 \\
\hline Jogging & 1 & 9 & & & 6 & 4 \\
\hline Swimming & & 1 & & & & 1 \\
\hline \multicolumn{7}{|c|}{ Exercise $<3 \mathrm{x} /$ week } \\
\hline Aerobic & & & 2 & 1 & 4 & \\
\hline Jogging & & & 1 & 1 & 2 & \\
\hline Swimming & & & 1 & & 1 & \\
\hline No exercise & & & 3 & 11 & 14 & \\
\hline
\end{tabular}

correlated with lifestyle changes such as starting to do regular exercises.

\section{Discussion}

Polycystic ovary syndrome (PCOS) is the most frequently encountered endocrinopathy in women of childbearing age. ${ }^{13}$ Various studies show that the prevalence of PCOS increases in reproductive age. ${ }^{14}$ The subjects of this study aged between 20-39 years. The BMI measurement determined the status of the weight as one of the risk factors for developing PCOS. The median body mass index of the subjects in this study was $23.0\left(16.9-37.1 \mathrm{kgBW} / \mathrm{m}^{2}\right)$ with $2 \%$ underweight, 48\% normoweight, and 50\% excessive weight (overweight, 20\%, and obese, $30 \%$ ).

Of all subjects, 34 (74\%) had an elevated leptin level with a median of $12.9 \mathrm{ng} / \mathrm{mL}$ (range 7.1 $\mathrm{ng} / \mathrm{mL}-19.1 \mathrm{ng} / \mathrm{mL})$. As expected, the leptin level increases in PCOS. Therefore, a high level of leptin plays a role in the pathogenesis of hyperandrogenism in PCOS. Jalilian et al. ${ }^{15}$ revealed that there is an association between elevated serum leptin levels and BMI in PCOS. Leptin resistance and lifestyle (uncontrolled diet and exercise) can cause Leptin level to increase in $62 \%$ subjects who had excessive BMI (overweight 21\% and obese 41\%). Leptin resistance is caused by impaired leptin signal transduction on neurons in the hypothalamus. These leptin signals are protein of suppressors of cytokine signaling 3 (SOCS3), protein tyrosine phosphatase 1B (PTP1B), and receptor leptin of signal transducers and activator of transcription 3 (STAT3). They are molecules known to weaken leptin signaling. The high leptin level due to leptin resistance interacts with the hypothalamic axis, hence causing reproduction dysfunction. ${ }^{16}$ Leptin resistance plays a role in steroidogenesis in ovarian granulosa cells which contributes to increased androgens in ovarian theca cells. ${ }^{13}$ In leptin resistance, leptin level is high but nonfunctioning. that the BMI remains above normal. Uncontrolled lifestyle factors (eating patterns and irregular exercise) can affect excessive BMI. Subjects who had excessive BMI (overweight and obese) in this study did not do the exercise as recommended i.e. more than 3 times a week with a duration of approximately 30 minutes. Stenervictorin et al. ${ }^{17}$ stated that light exercise such as brisk walking for 30 minutes with a frequency of 3 days a week may influence the BMI while Shetty et al. ${ }^{18}$ proposed that it can be achieved through aerobic exercise for 20-60 minutes with a frequency of 5 days a week for 12-24 weeks.

The study concluded that the mild-moderate exercise could increase fertility because it would increase blood flow and antioxidant status in women with PCOS. ${ }^{19}$ Leptin level was found to increase in 13 subjects with normoweight BMI while 9 subjects with normoweight BMI had a normal leptin level. This shows that leptin level can function physiologically in controlling the appetite center and energy metabolism. Of all subjects, 22 subjects had a normal BMI and 12 subjects routinely performed aerobic exercises, 9 subjects performed jogging, and 1 went swimming more than 3 times a week and a duration of exercise of approximately 30 minutes. The normal level of leptin hormone was present in two PCOS subjects with overweight BMI. This was achieved after changes of lifestyle, such as performing diet and regular exercises 
combined with medical therapy (metformin). Both overweight subjects did aerobic exercise more than three times a week with a duration of approximately 30 minutes. In addition, they consumed metformin that can cause the leptin receptor of soluble OB-receptor (sOB-R) to decrease in the hypothalamus, reduce activity of cytochrome P450 17 $\alpha$-hydtoxylase (CYP17) in ovarian theca cells, and reduces steroidogenesis in the ovaries of the PCOS patients. Medical treatment with metformin can reduce body weight and decrease the leptin level due to the effect of metformin, i.e. inhibiting leptin secretion by inhibiting the signaling pathway of mitogen actived protein kinase (MAPK) in adipocytes. Additionally, this can also improve insulin sensitivity. ${ }^{9,20}$

One subject who was underweight was found to have a normal leptin level. This subject had a history of reproductive issue from a mother who experienced difficulty to have children and her sister also suffers from infertility. According to Azziz et al., ${ }^{3}$ PCOS sufferers who have infertile mothers and sisters due to PCOS have a 30-50\% risk of suffering from PCOS.

The limitation of this study is that the data on lifestyle changes related to dietary factors are difficult to trace because subjects were unable to recall the portion of food consumed accurately. Consequently, it was difficult to evaluate BMI. This study also did not include normal controls, preventing comparison to be done between normal control and subjects with PCOS.

It can be concluded that in patients with PCOS, the higher the BMI is, the higher the level of leptin hormone. Nevertheless, it is necessary to change lifestyle into a healthier one by, for example, incorporating regular exercise regimens and regulating dietary patterns by consuming balanced nutrition to achieve a normal BMI. Examination of serum leptin level can be considered to determine the leptin status of patients with PCOS as a consideration in deciding treatments to prevent leptin resistance.

\section{References}

1. Goodarzi MO, Dumesic DA, Chazenbalk G, Azziz R. Polycystic ovary sindrome: etiology, pathogenesis and diagnosis. Nat Rev Endocrinol. 2011;7:219-31.

2. Barbieri RL. Polycystic ovary syndrome: diagnosis and management. J Clin Endocrinol Metab. 2014;8(10):1.

3. Azziz R, Carmina E, Chen Z, Dunaif A, Laven
JSE, Legro RS, etal. Polycystic ovary syndrome. Nat Rev Dis Primers. 2016;2:16057.

4. Sirmans SM, Pate KA. Epidemiology, diagnosis, and management of polycystic ovary syndrome. Clin Epidemiol. 2014;6:113.

5. Santoso B. Sindroma ovarium polikistik: problem reproduksi dan tantangannya terkait dengan gaya hidup perempuan Indonesia. Yogyakarta: ADLN-Perpustakaan Universitas Airlangga Fakultas Kedokteran Universitas Airlangga. 2014 [online] Available from: http://repository.unair. ac.id/40072/1/gdlhub-gdl-grey-2016santosobud-40453-pg.12-14-s.pdf

6. Yau TT, Ng NY, Cheung L, Ma RC. Polycyctic ovary syndrome: a common reproductive syndrome with long-term metabolic consequences. Hongkong Med J. 2017;23(6):622-34.

7. Doran IH, Franks S. Genetic rodent models of obesity-associated ovarian dysfunction and subfertility: insights into polycystic ovary syndrome. Front Endocrinol. 2016;7(53):110.

8. Chen C-I, Hsu M-I, Lin S-H, Chang Y-CI, Hsu C-S, Tzeng C-R. Adiponectin and Leptin in Overwight/ obese and lean women with polycystic ovary syndrome. Gynecol Endocrinol. 2015;31(4):264-8.

9. Rizk NM, Sharif E. Leptin as well as free leptin receptor is associated with polycystic ovary syndrome in young women. Int J Endrocrinol. 2015;7:1-10.

10. Rojas J, Chavez M, Olivar L, Rojas M, Morillo J, Mejias J, et al. Polycystic ovary syndrome, insulin resistance, and obesity: navigating the pathophysiologic labyrinth. Int J Reprod Med. 2014;2014:1-17.

11. Esteghamati A, Zandieh A, Zandieh B, Khalilzadeh O, Meysamie A, Nakhjavani M, et al. Leptin cut-off values for determination of metabolic syndrome: third national surveillance of risk factors of noncommunicable diseases in Iran. Endocrine. 2011;40(1):117-23.

12. Lim JU, Lee JH, Rhee Ck. Comparison of world Health Organization and Asia-Pacific body mass index classifications in COPD Patients. Int J Chron Obstruct Pulmon Dis. 2017;12:2465-75.

13. Chakrabarti J. Serum Leptin Level in women with polycystic ovary syndrome: correlation with adiposity, insulin, and circulating testosterone. J Ann Med Health Sci Res. 2013;3(2):191-6. 
14. Zhuang J, Liu Y, Xu L, Liu X, Zhou L, Tang L, et al. Prevalence of the Polycystic Ovary Syndrome in Female Residents of Chengdu, China. Gynecol Obstet Invest. 2014;77(4):217-23.

15. Jalilian N, Haghnazari L, Rasolinia S. Leptin and body mass index in polycystic ovary syndrome. India J Endocrinol Metab. 2016;20(3):324-8.

16. Amitani $M$, Asakawa $A$, Inui $A$. The role of leptin in the control of insulin-glucose axis. J Front Neurosci. 2013;7(51):1-12.

17. Stener-victorin E, Holm G, Janson PO, Gustafson D, Waern M. Acupunture and physical exercise for affective symtoms and health-related quality of life in polycystic ovary syndrome: secondary analysis from a randomized controlled trial. BMC complement Altern Med. 2013;13(131):1-8.

18. Shetty D, Chandrasekaran B, Singh AW,
Oliverraj J. Exercise in polycystic ovarian syndrome: An evidence-based review. Saudi J Sports Med. 2017;17:123-8.

19. Soebijanto S. Konsensus penanganan infertilitas. In: Hestiantoro A, Wiweko B, Pratama G, Yusuf D, editors. Konsensus penanganan infertilitas. Himpunan Endokrinologi Reproduksi dan Fertilitas indonesia (HIFERI); Perhimpunan Fertilisasi In Vitro Indonesia (PERFITRI); Ikatan Ahli Urologi Indonesia (IAUI); Perkumpulan Obstetri dan Ginekologi Indonesia (POGI). 2013. p. 1-83.

20. Upadhyaya P, Rehan HS, Seth V. Serum leptin changes with metformin treatment in polycystic ovarian syndrome: correlation with ovulation, insulin and testosterone levels. EXCLI J. 2011;10:9-15. 